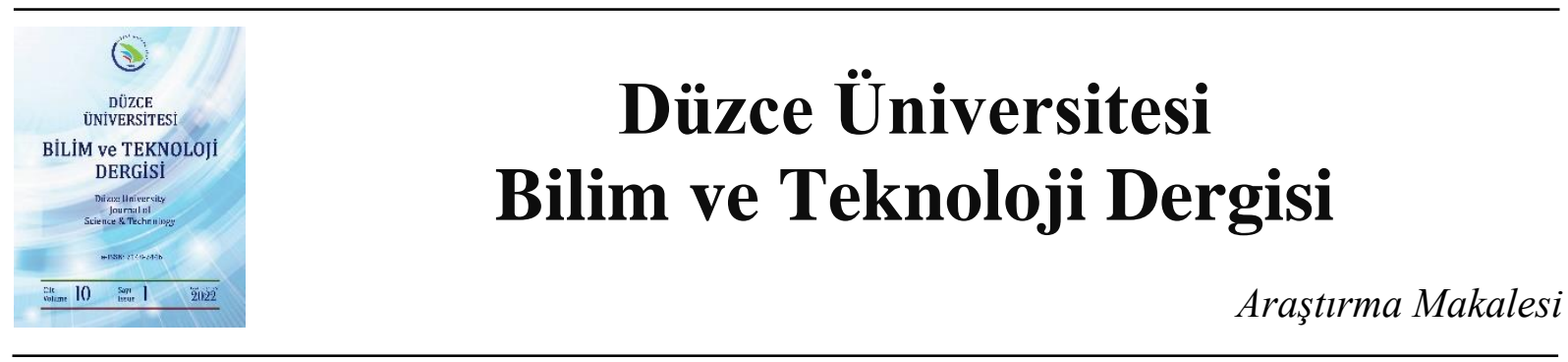

\section{Rekreasyon Amaçlı Mekânların Kullanımı Üzerine Bir Araştırma: "Düzce Üniversitesi Konuralp Kampüsü Örneği”"}

\author{
Serir UZUN ${ }^{\mathrm{a}, *}$ \\ ${ }^{a}$ Peyzaj Mimarlı̆̆ı Bölümü, Orman Fakültesi, Düzce Üniversitesi, Düzce, TÜRKIYE \\ * Sorumlu yazarin e-posta adresi: seriruzun@duzce.edu.tr
}

DOI: 10.29130/dubited.1030435

\begin{abstract}
Öz
Üniversiteler, öğrencilerin akademik eğitimle meslek edindikleri kurumlar olmalarının yanı sıra sosyal, kültürel ve psikolojik olarak da kendilerini geliştirdikleri, yetiştirdikleri ve olgunlaştıkları yerlerdir. Öğrencilerin hem bireysel hem de toplumsal gelişimleri üniversite kampüslerinin sahip olduğu rekreasyon amaçlı mekanları ve bu mekanların kullanımları ile doğrudan ilişkilidir. Bu çalışma ile öğrencilerin kampüslerin rekreasyon amaçlı mekanlarına ait kullanımlarını, kullanım tercihlerini ve yeterliliklerini değerlendirmeleri amaçlanmıştır. Çalışmanın yapıldığı Şubat-Haziran 2019 tarihleri arasında eğitim-öğretim gören 15.339 ön lisans ve lisans öğrencileri evreni oluşturmuş ve 388 öğrenci ile yüz yüze görüşme yöntemiyle anket çalışması uygulanmıştır. Çalışma sonucunda kız öğrencilerin yeşil alanları, erkek öğrencilerin spor alanlarını daha çok kullandıkları belirlenmiştir. Kız öğrenciler yeşil alanları sohbet etmek amaçlı kullanırken, erkeklerin en çok futbol sahalarını, sağlıkçıların ise yüzme havuzlarını kullandıkları görülmüştür. Öğrencilerin genel olarak kampüsteki yeşil alanları, spor alanlarını ve kültürel alanları yetersiz buldukları belirlenmiştir. Sosyal alanında eğitim gören öğrenciler tiyatro, sergi vb. alanlarını, fen alanında eğitim gören öğrenciler ise konferans salonlarını yetersiz bulmuşlardır.
\end{abstract}

Anahtar Kelimeler: Rekreasyon, Rekreasyon amaçlı mekan, Kampüs, Düzce Üniversitesi

\section{A Study on the Use of Recreational Spaces: "The Case of Düzce University Konuralp Campus"}

\begin{abstract}
Universities are the places where students develop, train and mature themselves socially, culturally and psychologically, as well as being institutions where they gain a profession through academic education. Both the individual and social development of students are directly related to the recreational spaces of the university campuses and the use of these spaces. With this study, it is aimed to evaluate the use, usage preferences and qualifications of the recreational areas of the campuses. The universe of 15,339 associate and undergraduate students studying between February and June 2019, when the study was conducted, formed the universe and a survey was conducted with 388 students by face-to-face interview method. As a result of the study, it was determined that female students use green areas more and male students use sports areas more. It was observed that while female students used the green areas to chat, boys mostly used the football fields and the health professionals used the swimming pools. It was determined that the students generally found the green areas, sports areas and cultural areas on the campus insufficient. Students studying in the field of social work, theater, exhibition, etc. students in the field of science found the conference halls insufficient.
\end{abstract}

Keywords: Recreation, Recreational space, Campus, Duzce University

Geliş: 30/11/2021, Düzeltme: 10/12/2021, Kabul: 13/12/2021 


\section{GIRIS}

Ülkelerin ekonomik, sosyal ve kültürel yönden kalkınıp gelişebilmesi açısından büyük öneme sahip olan üniversiteler genel anlamda; ülkenin ihtiyaç duyduğu hizmet alanlarına uzman işgücü yetiştirirken aynı zamanda toplum yararı için araştırmaların yapılarak bilgilerin üretildiği, bu bilgilerin yayılmasının ve gelecek kuşaklara aktarılmasının sağlandığı öğretim ve araştırma kurumları olarak tanımlanmaktadır $[1,2,3]$. Üniversitelerin hem üzerlerine düşen görevleri tam olarak yerine getirebilmeleri hem de başarılı olabilmeleri için toplumda meydana gelen değişimlere bağlı olarak gelişim göstermeleri elzemdir. Geçmişten günümüze kadar üniversitelerin eğitim verdiği alanlar irdelendiğinde; içinde bulundukları dönemdeki toplumun sosyo-kültürel yapısı, hızla artan nüfus ve buna bağlı bilimsel araştırma ve meslek eğitimine artan talepler, üniversitelerin bünyesinde oluşan değişimler, yeni ihtiyaçlar ve istekler ile tek bir yapıdan, birden çok işlevin aynı alanda yapılabildiği kent içi ve kent dışı kampüs modellerine kadar değişimlerin yaşandığı görülmektedir [4,3].

Türkçe yerleşke anlamına gelen kampüs; araştırma ve eğitim merkezlerinin, öğrenci yurtlarının, öğretim üyeleri lojmanlarının, sosyal tesislerin, açık yeşil alanlar, spor alanları, yürüme yolları ve kültürel alanlar gibi rekreasyon alanlarının, meydanların ve alışveriş mekanlarının kapladığı birçok işlevi bir arada barındıran bir eğitim alanıdır [5,6]. Üniversite kampüsleri çalışma, barınma, rekreasyon ve ulaşım gibi üzerinde taşıdığı işlevler doğrultusunda; akademik bölge, idari bölge, barınma bölgesi ve rekreasyon bölgesi olmak üzere dört ana bölümden meydana gelmektedir [7].

Çalışmanın konusu da olan kampüslerin rekreasyon bölgeleri öğrencilerin, öğretim üyelerinin ve memurların boş zamanlarını çeşitli aktiviteler ile zenginleştirerek eğlenme ve dinlenmelerine imkan veren mekanlardır. Bu rekresyon amaçlı mekanlar açık ve yeşil alanları, spor tesislerini ve kültürel tesisleri kapsamaktadırlar. Spor tesisleri; farklı spor aktivitelerinin yapılmasına imkan veren açık ve kapalı spor alanlarını; kültürel tesisler; konferans, kongre, sempozyum ve çalıştay gibi toplantı faaliyetlerinin yer aldığı salonları, sinema, tiyatro, konser ve sergi alanlarını, hobi atölyelerini ve alışveriş, yeme, içme vb. ihtiyaçlarını karşılayabildikleri açık ve kapalı mekânları; açık ve yeşil alanlar ise; kampüsün sınırlarını, bahçelerini, açık mekanda oturma ve dinlenme alanlarını, oyun alanlarını, anıt, yönlendirme tabelaları, çeşme ve donatı elemanlarını (aydınlatma, çöp kutusu, bank, pergola vb.) ve kampüs alanının ormanlık alanları, küçük gölleri ve kayalık alanları gibi doğal güzelliklerini içermektedirler $[8,9]$.

Kampüslerdeki rekreasyon amaçlı mekanlar; öğrencilere ders saatleri dışındaki vakitlerinde çeşitli etkinliklere katılmaları, farklı yörelerden gelen farklı gelenek ve göreneklere sahip öğrencilerin kültürel etkileşimler sağlamaları, öğrenci ve öğretim üyeleri arasındaki ilişkiyi kültürel ve sosyal açıdan da geliştirmeleri, disiplinler arası bağlantı ve ilişkiler kurularak bilgi paylaşımları yapılacak ortamlar yaratmaları, öğrencilere meslek eğitimi dışındaki sergi, müzik, tiyatro, spor karşılaşmaları vb. faaliyetlere katılma imkanı vermeleri ve öğrencilere kampüs yaşamında verdiği rollerle toplum hayatına hazırlamaları açışından oldukça önem taşımaktadır [10,11,12]. Ayrıca bu mekânlar kent ve kentli ile bütünleşmeyi sağlamak açısından da oldukça önem arz etmektedirler [13]. Bu nedenle öğrencilerin akademik eğitimle mesleki açıdan yetişmelerinde önemli rol oynayan üniversitelerin öğrencilerin sosyal, psikolojik ve kültürel anlamda da gelişmelerini sağlamak için hem akademik, hem fiziksel hem de sosyal kalitelerinin yüksek olması gerekmektedir. Bu çalışma ile Düzce Üniversitesi merkez kampüsünde eğitim gören öğrencilerin kampüsün rekreasyon amaçlı mekanlarının kullanımı ile ilgili kişisel görüşlerinin alınması ve bu alanların yeterliliklerinin değerlendirilmesi amaçlanmaktadır.

\section{MATERYAL ve METOT}

Çalışma alanı Düzce ilinde bulunan yaklaşık 168 ha arazi üzerinde kurulu olan Düzce Üniversitesi Konuralp (Merkez) Kampüsüdür (Şekil 1). Düzce Üniversitesi Konuralp kampüsünde 11 fakülte, 1 enstitü, 2 meslek yüksekokulu, 1 yüksekokul, 1 araştırma hastanesi, 30 araştırma merkezi, merkez 
kütüphane, sosyal tesis, şenliklerin yapıldığı ortak alan, spor merkezi (stadyum, olimpik yüzme havuzlar1, tenis, voleybol ve basketbol sahaları, kapalı spor salonu, fitnes salonu vb.) ve sosyal aktivite alanları bulunmaktadır. Yapısal alanların dışında rekreasyonel ihtiyaçları karşılama için geniş yeşil alanları, piknik alanı ve yapımı halen devam etmekte olan botanik bahçesi de bulunmaktadır.

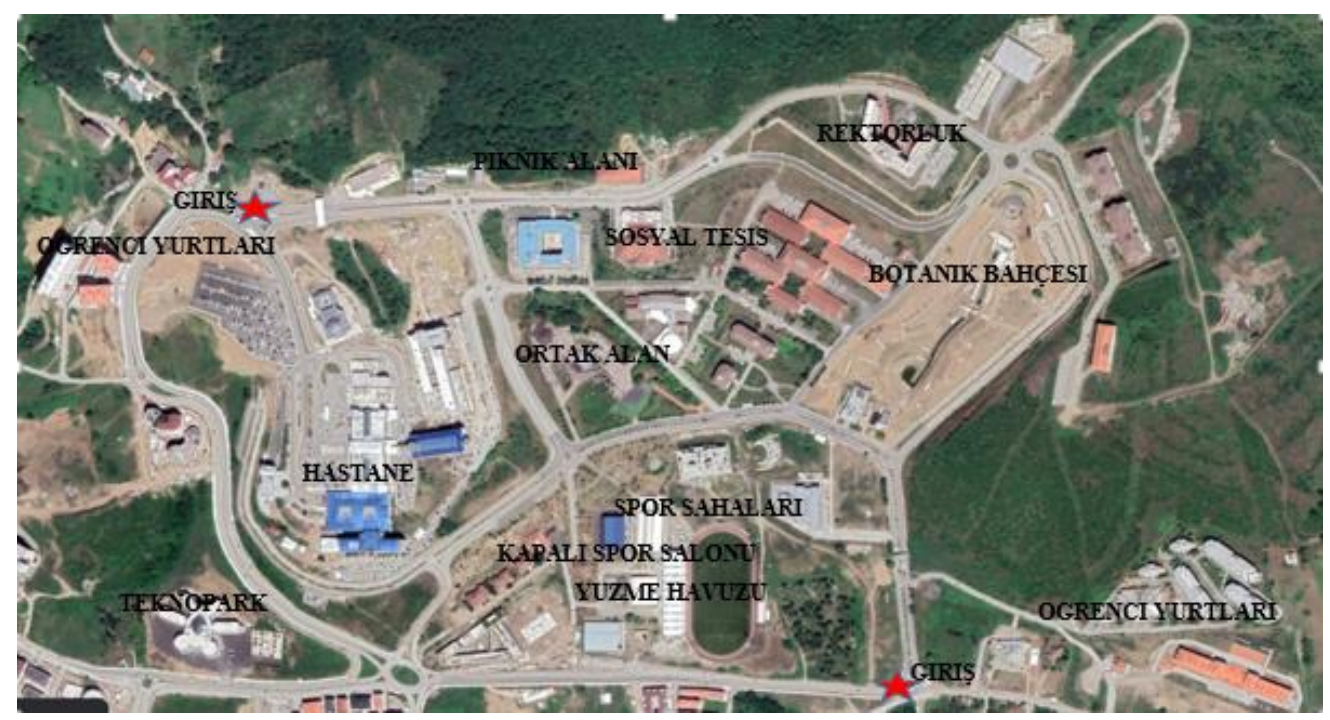

Şekil 1. Düzce Üniversitesi Konuralp Kampüsü

Araştırmanın evreni Düzce Üniversitesi Konuralp kampüsünde çalışmanı yapıldığ tarihleri arasında 11 fakülte ve 2 meslek yüksekokulunda eğitim-gören 15.339 ön lisans ve lisans öğrencilerinden oluşmaktadır (Tablo 1). Evreni temsil edecek örneklem büyüklüğünün belirlenmesinde $\% 95$ güven düzeyi ve $\% 5$ hata payı dikkate alınarak 375 öğrenciye ulaşılması gerektiği belirlenmiştir [14]. Çalışma kapsamında 2019 yılı Şubat-Haziran ayları arasında 388 öğrenci ile yüz yüze görüşme yöntemiyle anket çalışması yapılarak veriler elde edilmiştir.

Tablo 1. Araştırma kapsamında anket uygulanan fakülte/meslek yüksekokulları ve anket sayısı

\begin{tabular}{|c|c|c|c|c|}
\hline Eğitim alanı & Fakültte & Cinsiyet & Sayı & $\begin{array}{l}\text { Elde edilen } \\
\text { anket sayısI }\end{array}$ \\
\hline \multirow[t]{12}{*}{ Fen } & \multirow[t]{2}{*}{ Orman Fakültesi } & Kız & 245 & 17 \\
\hline & & Erkek & 440 & 13 \\
\hline & \multirow[t]{2}{*}{ Fen Edebiyat Fakültesi } & $\mathrm{K} 1 \mathrm{z}$ & 1143 & 16 \\
\hline & & Erkek & 586 & 14 \\
\hline & \multirow[t]{2}{*}{ Mühendislik Fakültesi } & $\mathrm{K} 1 \mathrm{z}$ & 810 & 32 \\
\hline & & Erkek & 2225 & 23 \\
\hline & \multirow[t]{2}{*}{ Teknoloji Fakültesi } & $\mathrm{K} 1 \mathrm{z}$ & 407 & 12 \\
\hline & & Erkek & 1781 & 31 \\
\hline & \multirow[t]{2}{*}{ Teknik Eğitim Fakültesi } & $\mathrm{K} 1 \mathrm{z}$ & 3 & 4 \\
\hline & & Erkek & 58 & 6 \\
\hline & \multirow[t]{2}{*}{ Ormancılık Meslek Yüksekokulu } & $\mathrm{K} 1 \mathrm{z}$ & 16 & 9 \\
\hline & & Erkek & 75 & 11 \\
\hline \multirow[t]{8}{*}{ Sosyal } & \multirow[t]{2}{*}{ İşletme Fakültesi } & $\mathrm{K} 1 \mathrm{z}$ & 1563 & 27 \\
\hline & & Erkek & 1551 & 28 \\
\hline & \multirow[t]{2}{*}{ Eğitim Fakültesi } & Kiz & 1101 & 17 \\
\hline & & Erkek & 402 & 13 \\
\hline & \multirow[t]{2}{*}{ İlahiyat Fakültesi } & $\mathrm{K} 1 \mathrm{z}$ & 382 & 12 \\
\hline & & Erkek & 151 & 13 \\
\hline & \multirow{2}{*}{ Spor Bilimleri Fakültesi } & $\mathrm{K} 1 \mathrm{z}$ & 132 & 17 \\
\hline & & Erkek & 431 & 13 \\
\hline
\end{tabular}


Tablo 1 (devam). Araştırma kapsamında anket uygulanan fakülte/meslek yüksekokulları ve anket sayısı

\begin{tabular}{llllr}
\hline Sağlık & Tıp Fakültesi & Kız & 460 & 17 \\
\cline { 3 - 5 } & & Erkek & 381 & 13 \\
\cline { 2 - 5 } & Sağlık Bilimleri Fakültesi & Kız & 410 & 11 \\
\cline { 3 - 5 } & & Erkek & 109 & 9 \\
\cline { 2 - 5 } & Sağlık Hizmetleri Meslek & Kız & 356 & 7 \\
\cline { 2 - 4 } & Yüksekokulu & Erkek & 121 & $\mathbf{3 8 8}$ \\
\hline Toplam & & & $\mathbf{1 5 . 3 3 9}$ & \\
\hline
\end{tabular}

Çalışmada uygulanan anket formunun oluşturulmasında konuyla ilgili literatür taraması yapılmış; Tolon [15], Erçevik [16], Ayvacı [4], Çınar [17], Düzenli [18], Erçevik ve Önal [12], Düzenli ve dĭg. [19], çalışmalarından yararlanılmıştır. Çalışmada kullanılan anket formu 4 bölüm, 17 soru ve 25 yargıdan oluşmaktadır. Anketin birinci bölümünde öğrenciler hakkında genel bilgiler 6 farklı soru ile sorgulanmıştır. Anketin ikinci bölümünde 7 farklı soru ve 14 yargı ile öğrencilerin kampüsteki açık ve yeşil alan kullanımı ve yeterliliği ele alınmıştır. Anketin üçüncü bölümünde 2 soru ve 11 yargı ile öğrencilere göre kampüsteki sporla ilgili alanların kullanımı ve yeterliliği ölçülmüştür. Anketin dördüncü bölümünde 2 soru ile kampüsteki kültürel alanların yeterliliği ve öğrencilerin kampüste yer almasını istedikleri alanlar sorgulanmıştır. Elde edilen anket sonuçları SPSS 22.0 programında kodlanarak veri seti oluşturulmuştur [20]. Oluşturulan veri seti üzerinden yapılan tanımlayıcı istatistiklerle frekans dağılımları ve ortalamalar bulunmuştur. Yargılar arasında bir ilişki olup olmadığına da ki-kare analizi yapılarak bakılmıştır.

\section{BULGULAR ve TARTISMA}

\section{A. GEÇERLILIK VE GÜVENIRLIK ANALIZİ}

Tablo 2'de çalışma kapsamında elde edilen verilere yapılan geçerlilik ve güvenilirlik analizine ait sonuçlar yer almaktadır. Çalışma kapsamında uygulanan anketlerin güvenirlik analizi Cronbach Alpha katsayısı ile hesaplanmıştır. Anketlerin geçerlilik analizi ise örnekleme yeterlilik ölçüsü (KMO) ve Barlett's küresellik testi ile ortaya konmuştur. Uygulanan analizlerin sonucunda tüm veriler için ölçeğin güvenilirlik değeri 0,824 olarak belirlenmiştir. Çalışmada kullanılan alt ölçeklerin güvenilirlik sonuçlarının ise 0,772 ve 0,776 olduğu hesaplanmıştır. Tüm bu sonuçların güvenilirlik açsından herhangi bir sorun teşkil etmediği belirlenmiştir. Ölçeğin geçerliliğini belirlemek için yapılan analizler sonucunda KMO değeri 0,785 ve Bartlett'in Küresellik testi sonucu 2298,696; serbestlik derecesi (df) 300 ve önem düzeyi de (p) 0,000 olarak hesaplanmıştır. Bu sonuçlar çalışma kapsamında kullanılan ölçeğin geçerlilik açısından herhangi bir sorun oluşturmadığını göstermektedir [21,22].

Tablo2. Kullanılan anketin güvenilirlik ve geçerlilik sonuçları

\begin{tabular}{lccc}
\hline Çalışma Türüi & $\begin{array}{c}\text { Güvenilirlik Sonucu } \\
\text { Cronbach Alpha Katsayısı }\end{array}$ & $\begin{array}{c}\text { Geçerlilik Analizi } \\
\text { Değeri }\end{array}$ & $\begin{array}{c}\text { Barlett } \\
\text { Değeri }\end{array}$ \\
\hline $\begin{array}{l}\text { Kampüsün yeşil alanlarının çok sık } \\
\text { kullanılmama nedeni }\end{array}$ & 0,772 & \\
\cline { 1 - 2 } $\begin{array}{l}\text { Kampüs içindeki yürüyüş yollarının yetersiz } \\
\text { görülme nedenleri }\end{array}$ & 0,776 & 0,785 & 2298,696 \\
\hline Tüm yargılar & 0,824 & \\
\hline
\end{tabular}

\section{B. ÖĞRENCILERE AITT GENEL BİLILER}

Çalışmaya katılan öğrencilerin cinsiyetlerine bakıldığında; \%51'inin kız, \%49'unun erkek olduğu; yaşlarına bakıldığında \%59,8'inin 21-23 yaş arasında, \%34,8'inin 20 ve daha altı yaşta olduğu 
görülmektedir. Öğrencilerin eğitim alanları değerlendirildiğinde \%48,4'ünün fen alanında, \%36,1'inin sosyal alanında ve \%15,5'inin sağlık alanında eğitim gördüğü belirlenmiştir. Öğrencilerin sınıf düzeylerine bakıldığında \%39,7'sinin 2. sınıfta, 31,7'sinin 3. sınıfta ve \%17,3'ünün 4. sınıfta okuduğu görülmektedir. Öğrencilerin konakladıkları yerler değerlendirildiğinde \%35,6'sının öğrenci evlerinde, \%25,5'inin özel yurt/apart dairelerde ve \%20,4'ünün devlet yurdunda kaldığı belirlenmiştir (Tablo 3).

Tablo 3. Öğrencilere ait genel bilgiler

\begin{tabular}{|c|c|c|c|}
\hline \multicolumn{2}{|c|}{ Kullanıcıların genel özellikleri } & \multirow{2}{*}{$\begin{array}{c}\text { Sayı } \\
(N) \\
198 \\
\end{array}$} & \multirow{2}{*}{$\begin{array}{c}\text { Oran } \\
(\%)\end{array}$} \\
\hline Cinsiyet & $\mathbf{K} \mathbf{z z}$ & & \\
\hline & Erkek & 190 & 49,0 \\
\hline \multirow[t]{3}{*}{ Yaş } & 20 ve daha düşük yaş & 135 & 34,8 \\
\hline & $21-23$ arası yaş & 232 & 59,8 \\
\hline & 24 ve daha büyük yaş & 21 & 5,4 \\
\hline \multirow[t]{3}{*}{ Eğitim Alanı } & Fen & 188 & 48,4 \\
\hline & Sosyal & 140 & 36,1 \\
\hline & Sağlik & 60 & 15,5 \\
\hline \multirow[t]{4}{*}{ Sinif } & 1. sinif & 44 & 11,3 \\
\hline & 2. sinif & 154 & 39,7 \\
\hline & 3. sinif & 123 & 31,7 \\
\hline & 4. $\sin 1 f$ & 67 & 17,3 \\
\hline \multirow{5}{*}{ Konaklama Yeri } & Devlet yurdu & 79 & 20,4 \\
\hline & Özel yurt/apart daire & 99 & 25,5 \\
\hline & Öğrenci evi & 138 & 35,6 \\
\hline & Aile ile & 63 & 16,2 \\
\hline & Günübirlik gidip gelme & 9 & 2,3 \\
\hline Toplam & & 388 & 100 \\
\hline
\end{tabular}

\section{KAMPÜSÜN AÇIK VE YEŞİL ALANLARININ KULLANIMI VE YETERLILİĞİ}

Ankete katılan öğrencilerin \%52,6'sının kampüste günlük ortalama 5-6 saat geçirdikleri ve öğrencilerin \%70,4'ünün kampüsteki yeşil alanlarını günlük 1-3 saat arası kullandıkları belirlenmiştir. Öğrencilerin hafta içi yeşil alanları kullanma sıklığına bakıldığında \%28,6'sının 4 saat ve üzeri, 25,5'inin 2 saat kullandıkları, hafta sonu yeşil alanları kullanma sıklığına bakıldığında ise \%28,9'unun 1 saat ve \%28,9'unun 2 saat kullandıkları görülmüştür. Kampüsteki yeşil alanları öğrencilerin \%38,7'si ders sonrası kullandığını ve \%30,9'u ise dersleri olmadığı zamanlar kullandığını belirtmiştir (Tablo 4). Erçevik ve Önal (2011) üniversite kampüslerinde sosyal mekânların kullanımları üzerinde yaptıkları çalışmalarında üniversite öğrencilerinin üniversitelerinin sosyal ve kültürel alanlarını en fazla dersleri olmadığı zamanlarda daha sonra da ders öncesi ve sonrası zamanlarda kullandıklarını belirtmişlerdir [12]. McFarland ve diğ. (2008) Texas State Üniversite'sinde lisans öğrencilerinin kampüs yeşil alanlarının kullanımı ile yaşam kalitesi algıları arasındaki ilişkiyi araştırdıkları çalışmada; öğrencilerin \%66,8’inin kampüs yeşil alanlarını yüksek düzeyde kullandıklarını belirtmişlerdir [23].

Tablo 4. Öğrencilerin kampüsteki açık ve yeşil alan kullanımları

\begin{tabular}{llcc}
\hline & Seçenekler & $\begin{array}{c}\text { Sayı } \\
(N)\end{array}$ & $\begin{array}{c}\text { Oran } \\
(\%)\end{array}$ \\
\hline $\begin{array}{l}\text { Kampüste günlük ortalama } \\
\text { kaç saat geçiriyorsunuz? }\end{array}$ & 1-2 saat & 30 & 7,7 \\
\cline { 2 - 4 } & 3-4 saat & 44 & 11,3 \\
\cline { 2 - 4 } & $\mathbf{5 - 6}$ saat & $\mathbf{2 0 4}$ & $\mathbf{5 2 , 6}$ \\
\cline { 2 - 4 } & 7 saat ve üstü & 110 & 28,4 \\
\hline $\begin{array}{l}\text { Kampüsteki yeşil alanları ne } \\
\text { siklıkla kullanıyorsunuz? }\end{array}$ & Kullanmiyorum & 89 & 22,9 \\
\cline { 2 - 4 } & Günlük 1-3 saat & $\mathbf{2 7 3}$ & $\mathbf{7 0 , 4}$ \\
\cline { 2 - 4 } & Günlük 4-6 saat & 26 & 6,7 \\
\hline
\end{tabular}


Tablo 4 (devam). Öğrencilerin kampüsteki açık ve yeşil alan kullanımları

\begin{tabular}{|c|c|c|c|}
\hline \multirow{5}{*}{$\begin{array}{l}\text { Hafta içi yeşil alanları ne } \\
\text { sıklıkla kullanıyorsunuz? }\end{array}$} & Kullanmiyorum & 50 & 12,9 \\
\hline & 1 saat & 86 & 22,2 \\
\hline & 2 saat & 99 & 25,5 \\
\hline & 3 saat & 42 & 10,8 \\
\hline & 4 saat ve üzeri & 111 & 28,6 \\
\hline \multirow{5}{*}{$\begin{array}{l}\text { Hafta sonu yeşil alanları ne } \\
\text { sıklıkla kullanıyorsunuz? }\end{array}$} & Kullanmiyorum & 89 & 22,9 \\
\hline & 1 saat & 112 & 28,9 \\
\hline & 2 saat & 112 & 28,9 \\
\hline & 3 saat & 60 & 15,5 \\
\hline & 4 saat ve üzeri & 15 & 3,3 \\
\hline \multirow{5}{*}{$\begin{array}{l}\text { Kampüsteki yeşil alanları en } \\
\text { fazla hangi zaman diliminde } \\
\text { kullanıyorsunuz? }\end{array}$} & Ders öncesi & 52 & 13,4 \\
\hline & Ders sonrası & 150 & 38,7 \\
\hline & Dersim olmadığı zamanlar & 120 & 30,9 \\
\hline & Tatil günlerinde & 33 & 8,5 \\
\hline & Hiçbir zaman & 33 & 8,5 \\
\hline
\end{tabular}

Öğrencilerin cinsiyet değişkeni ile kampüsteki yeşil alanları kullanma sıklığı arasında istatistiksel bir iliş̧i tespit edilmiştir $(p<0,05)$. Kız öğrencilerin erkek öğrencilere oranla yeşil alanları daha fazla günde 1-3 saat arası kullandıkları belirlenmiştir. McFarland ve diğ. (2008) yaptıkları çalışmada erkek öğrencilerin kadın öğrencilerden daha yüksek oranda yeşil alanları kullanma eğiliminde olduğunu belirtmişlerdir [23].

Öğrencilerin üniversite eğitim alanları ile kampüste günlük ortalama geçirdikleri saat arasında istatiksel anlamda bir ilişki bulunmaktadır ( $\mathrm{p}<0,05)$. Fen ve sosyal alanında eğitim gören öğrencilerin en çok 5-6 saat arasında kampüste zaman geçirdikleri, sağlık alanında eğitim gören öğrencilerin ise 7 saatten daha fazla zaman geçirdikleri belirlenmiştir. Bunda sağlık alanında eğitim gören öğrencilerin kampüste bulunan üniversite hastanesinde uygulama dersleri için çalışmalarının etkili olduğu söylenebilir.

Öğrencilerin sınıf düzeyleri ile kampüste günlük ortalama geçirdikleri saat, kampüsteki yeşil alanları kullanma sıklı̆̆ı, hafta içi yeşil alanları kullanma sıklığı ve hafta sonu yeşil alanları kullanma sıklığ1 arasında istatiksel anlamda bir ilişki bulunmaktadır $(\mathrm{p}<0,05)$. Kampüste 5 saat ve üstü vakit geçirenlerin çoğunlukla 3. sınıfta okuyan öğrencilerin olduğu belirlenmiştir. Kampüsteki yeşil alanları hem gün içerisinde, hem de hafta içi ve hafta sonu günlerinde en çok 1. sınıfta okuyan öğrencilerin kullandığı görülürken; 2. sınıfta okuyan öğrencilerin ise yeşil alanları tüm bu kullanım zamanlarında en fazla kullanmayan grup oldukları görülmüştür. McFarland ve diğg. (2008) yaptıkları çalışmada üniversite öğrencilerin sınıf düzeyi arttıkça kampüsteki yeşil alan kullanımlarının azaldığını belirtmektedirler [23].

Öğrencilerin yeşil alanları kullanma amaçları değerlendirildiğinde arkadaşları ile sohbet etme $(1,45 \pm 0,498)$ ve sigara içme $(1,66 \pm 0,473)$ en etkili kullanma amacı olarak görülmekteyken; ders çalışma $(1,80 \pm 0,401)$, top oynama $(1,86 \pm 0,338)$ ve seyir amaçli $(1,89 \pm 0,311)$ olarak kullanma en az etkili amaç olarak görülmektedir (Tablo 5). Düzenli (2010) kampüs açık mekân olanaklarını gençlerin psikososyal yapısına bağlı olarak incelediği araştırmasında kampüs alanındaki yeşil alanları ögrencilerin \%43 oranla sohbet etme amacıyla kullandıklarını belirlemiştir [18]. McFarland ve diğ. (2008) yaptıkları çalışmada üniversite öğrencilerinin kampüsteki yeşil alanları daha çok sosyalleşmek için kullandıklarını belirtmişleridir [23]. Abu-Ghazzeh (1999) Ürdün Üniversitesi'nde davranış araştırmalarının kampüs tasarımına iletilmesi konulu araştırmasında; katılımcıların kampüs yeşil alanlarını daha çok sosyal etkileşim için tercih ettiklerini ortaya koymuştur [24].

Tablo 5. Öğrencilerin yeşil alanları kullanma amaçları

\begin{tabular}{lcc}
\hline Seçenekler & Arit. Ort*. & St. Sapma \\
\hline Sohbet etme & 1,45 & 0,498 \\
\hline Sigara içme & 1,66 & 0,473 \\
\hline
\end{tabular}


Tablo 5 (devam). Öğrencilerin yeşil alanları kullanma amaçları

\begin{tabular}{lcc}
\hline Uzanma/dinlenme & 1,70 & 0,457 \\
\hline Yeme-içme & 1,73 & 0,482 \\
\hline Müzik çalama/dinleme & 1,77 & 0,434 \\
\hline Piknik yapmak & 1,79 & 0,410 \\
\hline Ders çalışma & 1,80 & 0,401 \\
\hline Top oynama & 1,86 & 0,338 \\
\hline Seyir & 1,89 & 0,311 \\
\hline \multicolumn{2}{l}{}
\end{tabular}

Yeşil alanları kullanma amaçlarından sohbet etme yargısı ile öğrencilerin cinsiyet değişkeni arasında istatistiksel bir ilişki tespit edilmiştir $(p<0,05)$. Kız öğrencilerin erkek öğrencilerden daha fazla oranda bu yargıya katılım gösterdikleri belirlenmiştir. Speake ve diğ. (2013) Liverpool Hope Üniversitesi'nde kampüs yeşil alanlarının kullanımı üzerine yaptıkları araştırmada; kız öğrencilerin yeşil alanları daha çok sosyalleşme için kullanırken erkek öğrencilerin ise spor amaçlı kullandıklarını belirtmişlerdir [25].

Öğrencilerin üniversite eğitim alanları ile yeşil alanları kullanma amaçlarından sohbet etme ve yeme içme yargıları arasında istatistiksel bir ilişki tespit edilmiştir $(\mathrm{p}<0,05)$. Fen ve sosyal alanında eğitim gören öğrencilerin sağlık alanında eğitim gören öğrencilere oranla yeşil alanları daha çok sohbet etme amaçlı kullandıkları belirlenmiştir. Sosyal ve sağlık alanında eğitim gören öğrencilerin fen alanında eğitim gören öğrencilere oranla yeşil alanları daha çok yeme-içme amaçlı kullandıkları görülmüştür.

Öğrencilerin sınıf düzeyleri ile yeşil alanları kullanma amaçlarından sohbet etme, ders çalışma, müzik çalma/dinleme yargıları arasında istatistiksel bir ilişki tespit edilmiştir $(\mathrm{p}<0,05)$. Yeşil alanları sohbet etme amaçlı olarak en çok 2. sınıfta okuyan öğrencilerin, ders çalışma amaçlı olarak en çok 3 . ve 4. sınıfta okuyan öğrencilerin ve müzik çalma/dinleme amaçlı en çok 1. sinıfta okuyan öğrencilerin kullandıkları belirlenmiştir.

Öğrencilerin kampüsteki yeşil alanları kullanmama nedenlerine bakıldığında sırasıyla en çok "yeşil alanları yeterli bulmadıkları $(2,22 \pm 1,138)$ ", "yeşil alanları cazip bulmadıkları $(2,41 \pm 1,243)$ ", yeşil alanları mevsimlik kullanımlar açısından korunaklı bulmadıkları (gölgeleme/yağmur/rüzgâr vb.) $(2,45 \pm 1,175)$ ", "yeşil alanlardaki donatı elemanlarını (oturma, çöp, aydınlatma) yeterli bulmadıkları $(2,45 \pm 1,152)$ " ve "mekânda ilgi çekici doğal alanların yer almadığ 1 (göl, gölet, nehir vb.) $(2,45 \pm 1,251)$ " yargıları gelmektedir (Tablo 6). Ayvacı (2009) kampüslerdeki dış mekân tasarımında kullanıcı gereksinimlerini saptamaya yönelik yaptığı araştırmasında ankete katılan İstanbul Teknik Üniversitesi ve Ege Üniversitesinde okuyan öğrencilerin kampüs alanlarındaki ağaçlık ve çim alanları yeterli buldukları belirlenmiştir [4]. Erçevik ve Önal (2011) yaptıkları çalışmalarında üniversite öğrencilerinin kampüslerindeki sosyal ve kültürel alanları kullanmama nedenleri arasında en fazla etkinlik alanlarını yeterli bulmamaları ve cazip bulmamaları gelmektedir. Yine aynı çalışmada öğrencilerin büyük çoğunluğu etkinlik alanlarına ulaşmada problem yaşamadıklarını belirtmişlerdir [12] .

Tablo 6. Öğrencilerin kampüsteki yeşil alanları kullanmama nedenleri

\begin{tabular}{lcc}
\hline Seçenekler & Arit. Ort*. & St. Sapma \\
\hline Yeşil alanları yeterli bulmuyorum & 2,22 & 1,138 \\
\hline Yeşil alanları cazip bulmuyorum & 2,41 & 1,243 \\
\hline $\begin{array}{l}\text { Yeşil alanları mevsimlik kullanımlara korunaklı bulmuyorum } \\
\text { (gölgeleme/yağmur/rüzgar..) }\end{array}$ & 2,45 & 1,175 \\
\hline $\begin{array}{l}\text { Yeşil alanlardaki donatı elemanlarını (oturma, çöp, aydınlatma) yeterli } \\
\text { bulmuyorum }\end{array}$ & 2,45 & 1,152 \\
\hline Mekanda ilgi çekici doğal alanların yer almaması (göl, gölet, nehir vb.) & 2,45 & 1,251 \\
\hline $\begin{array}{l}\text { Değişik renk-form ve dokuya sahip bitkilerin yer almaması } \\
\text { (çiçek/ağaç/çalı/meyve) }\end{array}$ & 2,51 & 1,114 \\
\hline Yeşil alanları güvenli bulmuyorum (sokak hayvanları vb.) & 2,55 & 1,228 \\
\hline
\end{tabular}


Tablo 6 (devam). Öğrencilerin kampüsteki yeşil alanları kullanmama nedenleri

\begin{tabular}{lcc}
\hline Alanda sanatsal ögeleri (heykel, plastik objeler vb.) yetersiz buluyorum & 2,61 & 1,223 \\
\hline Yeşil alanlarda geçirecek kadar boş zamanım yok & 2,64 & 1,156 \\
\hline Yeşil alanların çok gürültülü olması & 2,65 & 1,140 \\
\hline Yeşil alanları temiz ve bakımlı bulmuyorum & 2,70 & 1,146 \\
\hline Yeşil alanların çok fazla kalabalık olması & 2,71 & 1,219 \\
\hline Yeşil alanlarda vakit geçirecek arkadaşım yok & 2,84 & 1,274 \\
\hline Yeşil alanlara ulaşım problemi yaşıyorum & 3,19 & 1,225 \\
\hline *1: Kesinlikle katılıyorum, 2: Katıllyorum, 3: Kararsızım, 4: Katılmıyorum, 5: Kesinlikle katılmıyorum
\end{tabular}

Öğrencilerin sınıf düzeyleri ile kampüsteki yeşil alanları kullanmama nedenleri yargılarından "yeşil alanları cazip bulmuyorum", "yeşil alanlardaki donatı elemanlarını (oturma, çöp, aydınlatma) yeterli bulmuyorum", "yeşil alanlarda değişik renk-form ve dokuya sahip bitkilerin yer almaması (çiçek/ağaç/çalı/meyve)", "yeşil alanlara ulaşım problemi yaşıyorum", "yeşil alanları temiz ve bakımlı bulmuyorum" yargıları arasında istatiksel anlamda bir ilişki bulunmaktadır $(\mathrm{p}<0,05)$. Yeşil alanların cazip olmadığına 1. ve 3. sınıfta okuyan öğrenciler en fazla oranda katılırken; yeşil alanlardaki donatı elemanlarının (oturma, çöp, aydınlatma) yeterli olmadığına 1. sınıfta okuyan öğrencilerin en fazla katılım gösterdikleri görülmüş̧ür. 4. sınıfta okuyan öğrencilerin yeşil alanlarda değişik renk-form ve dokuya sahip bitkilerin olmamasına, 3. sınıfta okuyan öğrencilerin ise yeşil alanların temiz ve bakımlı olmamasına diğer sınıflarda okuyan öğrencilerden daha düşük oranda katılım gösterdikleri belirlenmiştir.

\section{KAMPÜSÜN SPORLA İLGILİ ALANLARININ KULLANIMI VE YETERLİLIĞİ}

Ankete katılan öğrencilerin \%59,8'inin kampüsteki spor alanlarını kullandıkları, \%39,2'sinin spor alanlarını hafta sonları kullandıkları, \%34,6'sının da dersleri olmadıkları zaman kullandıkları belirlenmiştir (Tablo 7). Öğrenciler \%29,9 oranla en çok yürüyüş yollarını kullandıklarını ve \%13,1 oranla fitnes salonunu kullandıklarını belirmişlerdir.

Tablo7. Öğrencilerin kampüs spor alanlarını kullanımları

\begin{tabular}{|c|c|c|c|}
\hline & & $\begin{array}{c}\text { Sayı } \\
(N)\end{array}$ & $\begin{array}{l}\text { Oran } \\
(\%)\end{array}$ \\
\hline \multirow{2}{*}{$\begin{array}{l}\text { Kampüsteki spor alanlarını } \\
\text { kullanıyor musunuz? }\end{array}$} & Evet & 232 & 59,8 \\
\hline & Hayır & 156 & 40,2 \\
\hline \multirow{4}{*}{$\begin{array}{l}\text { Kampüsteki spor alanlarını ne } \\
\text { zaman kullanıyorsunuz? }\end{array}$} & Hafta içi & 78 & 20,1 \\
\hline & Hafta sonu & 152 & 39,2 \\
\hline & Her zaman & 44 & 11,3 \\
\hline & Hiçbir zaman & 114 & 29,4 \\
\hline \multirow{5}{*}{$\begin{array}{l}\text { Kampüsteki spor alanları en } \\
\text { fazla hangi zaman diliminde } \\
\text { kullanıyorsunuz? }\end{array}$} & Ders öncesi & 62 & 16 \\
\hline & Ders sonras1 & 71 & 18,3 \\
\hline & Öğlen arası & 27 & 6,9 \\
\hline & Dersim olmadığı zamanlar & 134 & 34,6 \\
\hline & Hiçbir zaman & 94 & 24,2 \\
\hline \multirow{8}{*}{$\begin{array}{l}\text { Kampüsteki en çok hangi spor } \\
\text { alanlarını kullanırsınız? }\end{array}$} & Yürüyüş yolları & 116 & 29,9 \\
\hline & Fitnes salonu & 51 & 13,1 \\
\hline & Yüzme havuzu & 40 & 10,3 \\
\hline & Futbol (stadyum) & 42 & 10,8 \\
\hline & Basketbol & 36 & 9,3 \\
\hline & Voleybol & 32 & 8,2 \\
\hline & Tenis & 27 & 7,0 \\
\hline & Kapalı spor salonu & 44 & 11,4 \\
\hline
\end{tabular}

Öğrencilerin cinsiyet değişkeni ile kampüsteki spor alanlarını kullanıp kullanma durumu ve en çok kullandıkları spor alanları türü arasında istatistiksel bir ilişki tespit edilmiştir $(p<0,05)$. Erkek 
öğrencilerin kız öğrencilere oranla spor alanlarını daha çok kullandıkları ve futbol alanlarını tercih ettikleri belirlenmiştir. Müderrisoğlu ve Uzun (2004) üniversite öğrencilerinin rekreasyonel eğilimlerini belirlemek amacıyla yaptıkları çalışmalarında cinsiyetle futbol oynamak arasında \%59 oranında ilişki olduğunu ve erkek öğrencilerin futbolu tercih ettiklerini belirlemişlerdir [26]. Coakley ve White (1992) ve Greendorfer (1993) tarafından yapılan benzer çalışmalarda da erkeklerin kadınlara oranla spor alanlarını daha çok tercih ettikleri belirlenmiştir $[27,28]$.

Öğrencilerin üniversite eğitim alanları ile kampüsteki spor alanlarını kullanıp kullanma durumu arasında istatistiksel bir ilişki tespit edilmiştir $(p<0,05)$. Sağl1k ve sosyal alanında eğitim gören öğrencilerin fen alanında eğitim gören öğrencilere oranla daha çok spor alanlarını kullandıkları görülmüştür. Sağl1k alanında eğittim gören öğrencilerin yüzme havuzlarını diğer eğitim alanlarında okuyan öğrencilere oranla daha çok tercih ettikleri görülmüş̧ür.

Ankete katılan öğrencilerin \%70,4'ü yürüyüş yollarını yetersiz bulduklarını belirtmişlerdir. Öğrenciler kampüsteki spor alanlarını değerlendirdiğinde ise \%44,3'ü yüzme havuzlarını, \%58,5'i tenis kortlarını, \%55,4'ü kapalı spor salonlarını ve \%46,4'ü ise fitnes salonunu yetersiz bulurken; \%39,2'si basketbol sahalarını, \%39,9'u voleybol sahalarını ve \%39,7'si futbol sahalarını (Stadyum) yeterli bulmaktadır (Tablo 8). Öğrencilerin basketbol, voleybol ve futbol sahalarını yeterli bulmalarının nedeni olarak devlet yurtlarının bu imkânlara sahip olması ve devlet yurdunda kalan öğrencilerin ihtiyaçlarını buralarda karşılamasının etkili olduğu söylenebilir. Ayvacı (2009) yaptığı araştırmasında ankete katılan İstanbul Teknik Üniversitesinde okuyan öğrencilerin \%40'1 basketbol sahasını, \%40'1 tenis sahasını, \%43'ü stadyumu yeterli bulurken, \%43'ü voleybol sahasını ve \%39'u yüzme havuzunu yetersiz bulmaktadır. Ege Üniversitesinde okuyan öğrencilerin \%51'i stadyumu, \%65'i yüzme havuzunu yeterli bulurken, \%40'1 basketbol sahasını, \%43'ü voleybol sahasını ve \%37'si tenis sahasını yetersiz bulmaktadır. Yine aynı çalışmada İstanbul Teknik Üniversitesinde okuyan öğrencilerin \%38'i "kampüsteki yaya yolları dar" önermesine katıllyorum derken, Ege Üniversitesinde okuyan öğrencilerin \%41'i kesinlikle katılıyorum yanıtını vermiştir [4].

Tablo 8. Kampüs spor alanlarının ögrenciler tarafindan dĕgerlendirilmesi

\begin{tabular}{|c|c|c|c|}
\hline & & $\begin{array}{c}\text { Sayı } \\
(N)\end{array}$ & $\begin{array}{c}\text { Oran } \\
(\%)\end{array}$ \\
\hline \multirow[t]{3}{*}{ Yürüyüş yolları } & Yeterli & 84 & 21,6 \\
\hline & Yetersiz & 273 & $\mathbf{7 0 , 4}$ \\
\hline & Fikrim yok & 31 & 8,0 \\
\hline \multirow[t]{3}{*}{ Yüzme havuzu } & Yeterli & 127 & 32,7 \\
\hline & Yetersiz & 172 & 44,3 \\
\hline & Fikrim yok & 89 & 22,9 \\
\hline \multirow[t]{3}{*}{ Tenis kortu } & Yeterli & 61 & 15,7 \\
\hline & Yetersiz & 227 & 58,5 \\
\hline & Fikrim yok & 100 & 25,8 \\
\hline \multirow[t]{3}{*}{ Basketbol sahası } & Yeterli & 152 & 39,2 \\
\hline & Yetersiz & 141 & 36,3 \\
\hline & Fikrim yok & 95 & 24,5 \\
\hline \multirow[t]{3}{*}{ Voleybol sahası } & Yeterli & 155 & 39,9 \\
\hline & Yetersiz & 134 & 34,6 \\
\hline & Fikrim yok & 99 & 25,5 \\
\hline \multirow[t]{3}{*}{ Futbol sahası (Stadyum) } & Yeterli & 154 & 39,7 \\
\hline & Yetersiz & 113 & 29,1 \\
\hline & Fikrim yok & 121 & 31,2 \\
\hline \multirow[t]{3}{*}{ Kapalı spor salonu } & Yeterli & 77 & 19,8 \\
\hline & Yetersiz & 215 & 55,4 \\
\hline & Fikrim yok & 96 & 24,8 \\
\hline \multirow[t]{3}{*}{ Fitnes salonu } & Yeterli & 171 & 44,7 \\
\hline & Yetersiz & 180 & 46,4 \\
\hline & Fikrim yok & 37 & 9,5 \\
\hline
\end{tabular}


Yapılan analizler sonucunda öğrencilerin cinsiyeti ile kampüs spor alanlarında yürüyüş yollarını yeterli bulup bulmamas1 ve futbol sahalarını yeterli bulup bulmamas1 arasında istatistiksel olarak anlamlı bir iliş̧ki tespit edilmiş̧ir $(\mathrm{p}<0,05)$. Kız öğrenciler yürüyüş yollarını yetersiz bulurken; erkek öğrencilerin ise futbol sahalarını yetersiz buldukları belirlenmiştir.

Öğrencilerin eğitim alanları ile kampüs spor alanlarından voleybol sahalarını ve futbol sahalarını yeterli bulup bulmamaları arasında istatistiksel olarak anlamlı bir ilişki tespit edilmiştir $(p<0,05)$. Sosyal alanında eğitim gören öğrenciler için kampüsteki voleybol sahaları, futbol sahaları ve fitnes salonu yeterli görülürken; en çok sağlık alanında eğitim gören öğrenciler için bu alanlar yetersiz görülmüştür.

Öğrencilerin sınıf düzeyleri ile kampüs spor alanlarından yüzme havuzunun yeterli olup olmaması, basketbol sahalarının yeterli olup olmaması, voleybol sahalarının yeterli olup olmaması ve kapalı spor salonunun yeterli olup olmaması arasında istatistiksel olarak anlamlı bir ilişki tespit edilmiştir $(\mathrm{p}<0,05)$. Kampüs spor alanlarından yüzme havuzlarını, basketbol sahaların 2. sınıfta okuyan öğrencilerin; kapalı spor salonları ile voleybol sahalarını ise 4. sınıfta okuyan öğrencilerin diğer sınıf düzeylerinde okuyan öğrencilere oranla daha yetersiz gördükleri belirlenmiştir.

Ankete katılan öğrencilerin kampüs içindeki yürüyüş yollarını yetersiz görme nedenleri değerlendirildiğinde sırasıyla en çok kampüste "taşıt ve yaya trafiğinin ayrılmamış olmasından $(2,02 \pm 0,982)$ ", "yolların görsel açıdan tatmin edici olmamasından $(2,06 \pm 1,038)$ " ve "yolların çok eğimli olmasından $(2,09 \pm 1,041)$ " kaynaklandığı belirlenmiştir (Tablo 9). Ayvacı (2009) yaptığı araştırmasında ankete katılan İstanbul Teknik Üniversitesinde okuyan öğrencilerin \%38'i "kampüsteki yaya yolları dar" önermesine 'katıllyorum' derken, Ege Üniversitesinde okuyan öğrencilerin \%24,ü 'kesinlikle katılıyorum' yanıtını vermiştir [4].

Tablo 9. Öğrencilerin kampüsteki yürüyüs yollarını değerlendirmeleri

\begin{tabular}{lcc}
\hline Seçenekler & Arit. Ort*. & St. Sapma \\
\hline Taşıt ve yaya trafiğinin ayrılmamış olması & 2,02 & 0,982 \\
\hline Yolların görsel açıdan tatmin edici olmaması & 2,06 & 1,038 \\
\hline Yolların çok eğimli olması & 2,09 & 1,041 \\
\hline Yaya kaldırımlarının dar olması & 2,21 & 0,991 \\
\hline Engelliler için düzenleme yapılmamış olması & 2,26 & 1,054 \\
\hline Yaya yollarında kullanılan döş̧eme elemanlarının yürümeye & 2,29 & 1,098 \\
uygun olmaması & 2,30 & 1,054 \\
\hline Yollarda gölgelendirme amaçlı bitkilendirmenin olmaması & 2,33 & 1,121 \\
\hline Yol kenarlarında bank vb. oturma mekânların yeterli olmaması & 2,36 & 1,138 \\
\hline Yollarda merdivenlerin çok fazla olması & 2,43 & 1,036 \\
\hline Yönlendirme ve bilgilendirme levhalarının yeterli olmaması & 2,68 & 1,078 \\
\hline Aydınlatma elemanlarının eksik olması & & \\
\hline Kesinlikle katılıyorum, 2: Katılıyorum, 3: Kararsızım, 4: Katılmıyorum, 5: Kesinlikle katılmıyorum
\end{tabular}

Yapılan değerlendirmeler sonucunda öğrencilerin cinsiyet değişkeni ile kampüsteki yürüyüş yollarını yetersiz görme yargılarından "yol kenarlarında bank vb. oturma mekânlarının yeterli olmaması" ve "yaya yollarında kullanılan döşeme elemanlarının yürümeye uygun olmaması" yargıları arasında istatistiksel olarak anlamlı bir ilişki tespit edilmiştir $(p<0,05)$. Kız öğrencilerin erkek öğrencilere göre yürüyüş yollarında bank vb. oturma mekânlarının olmaması ve yollarda kullanılmış olan döşeme elemanlarının yürüyüş açısından uygun olmaması yargılarına daha fazla oranda katıldıkları belirlenmiştir.

Öğrencilerin üniversite eğitim alanları ile kampüsteki yürüyüş yollarını yetersiz görme yargılarından "taşıt ve yaya trafiğinin ayrılmamış olması" yargısı arasında istatiksel anlamda bir ilişki bulunmaktadır $(p<0,05)$. Sosyal alanda eğitim gören öğrencilerin taşıt ve yaya trafiğinin ayrılmamış olması yargısına diğer alanda eğitim gören öğrencilere göre daha yüksek oranda katıldıkları belirlenmiştir. 
Öğrencilerin sınıf düzeyleri ile kampüsteki yürüyüş yollarını yetersiz görme yargılarından "yollarda gölgelendirme amaçlı bitkilendirmenin olmaması" ve "aydınlatma elemanlarının eksik olması" yargıları arasında istatiksel anlamda bir ilişki bulunmaktadır $(\mathrm{p}<0,05)$. 2. sınıfta okuyan öğrenciler yollarda gölgelendirme sağlayacak bitkilendirmelerin olmadığı yargısına diğer sınıflarda okuyan öğrencilerden daha az katılmaktadırlar. 4. sınıf öğrencilerinin yollardaki aydınlatma elemanlarının eksik olması yargısına diğer sınıflarda okuyan öğrencilerden daha çok katıldıkları görülmektedir.

\section{KAMPÜSTEKİ KÜLTÜREL ALANLARIN YETERLILİĞININ ANALİİ}

Öğrenciler kampüsteki şenlik/konser alanlarını \%56,7 oranında, konferans alanlarını \%41,5 oranında ve tiyatro, sergi vb. alanları da \%53,6 oranında yetersiz bulduklarını belirtmişlerdir. Öğrenciler kampüsteki yeme-içme alanlarını değerlendirdiklerinde \%66'sı kafe-restoranları, \%61,9'u ise açık mekânlarda yeme içme olanaklarını yetersiz bulmaktadır. Öğrencilerin \%43,6'sı otoparkları yetersiz bulurken, \%21,4'ü otoparkların yeterliliği konusunda fikirlerinin olmadığını belirtmiştir (Tablo 10). Öğrencilerin otopark alanlarını yetersiz bulmalarındaki en büyük etkenin araçların yollara park edilmesi ve araç trafiğini oldukça etkilemesi bunun yanı sıra; fikri olmayan öğrencilerin sayısının çokluğunun da öğrencilerin büyük kısmının araç sahibi olmamalarından kaynaklandığı söylenebilir. Ayvacı (2009) yaptığı araştırmasında ankete katılan Ege Üniversitesi öğrencilerinin \%70'inin kampüsteki şenlik alanı için 'yetersiz' yanıtını verdiğini belirtmiş̧ir. Yine aynı araştırmada ankete katılan İstanbul Teknik Üniversitesinde okuyan öğrencilerin \%27'si kampüsteki otopark alanlarının yeterliliği hakkında 'fikrim yok' yanıtını verirken, Ege Üniversitesinde okuyan öğrencilerin \%29'u 'yeterli' yanıtını vermiştir [4].

Tablo 10. Kampüsün kültürel alanlarının öğrenciler tarafindan değerlendirilmesi

\begin{tabular}{llcc}
\hline \multirow{2}{*}{ Şenlik/konser alanları } & Yeterli & $\begin{array}{c}\text { Sayı } \\
(N)\end{array}$ & $\begin{array}{c}\text { Oran } \\
(\%)\end{array}$ \\
\cline { 2 - 4 } & Yetersiz & $\mathbf{2 2 0}$ & 22,7 \\
\cline { 2 - 4 } & Fikrim yok & 80 & $\mathbf{5 6 , 7}$ \\
\hline \multirow{2}{*}{ Konferans salonu } & Yeterli & 149 & 20,6 \\
\cline { 2 - 4 } & Yetersiz & $\mathbf{1 6 1}$ & $\mathbf{4 1 , 5}$ \\
\cline { 2 - 4 } & Fikrim yok & 78 & 20,1 \\
\hline Tiyatro, sergi vb. alanları & Yeterli & 121 & 31,2 \\
\cline { 2 - 4 } & Yetersiz & $\mathbf{2 0 8}$ & $\mathbf{5 3 , 6}$ \\
\cline { 2 - 4 } & Fikrim yok & 59 & 15,2 \\
\hline Kafe-Restoran & Yeterli & 47 & 12,1 \\
\cline { 2 - 4 } & Yetersiz & $\mathbf{2 5 6}$ & $\mathbf{6 6 , 0}$ \\
\cline { 2 - 4 } & Fikrim yok & 85 & 21,9 \\
\hline Açı mekânda yeme içme alanları & Yeterli & 65 & 16,8 \\
\cline { 2 - 4 } & Yetersiz & $\mathbf{2 4 0}$ & $\mathbf{6 1 , 9}$ \\
\cline { 2 - 4 } & Fikrim yok & 83 & 21,4 \\
\hline Otopark & Yeterli & 136 & 35,1 \\
\cline { 2 - 4 } & Yetersiz & $\mathbf{1 6 9}$ & $\mathbf{4 3 , 6}$ \\
\cline { 2 - 4 } & Fikrim yok & 83 & 21,4 \\
\hline
\end{tabular}

Öğrencilerin eğitim alanları ile kampüsün kültürel alanlarından tiyatro vb. alanlarının yeterli olup olmaması ve konferans salonlarının yeterli olup olmaması arasında istatistiksel olarak anlamlı bir ilişki tespit edilmiştir $(p<0,05)$. Sosyal alanında eğitim gören öğrenciler için kampüsteki tiyatro, sergi vb. alanlar daha yüksek oranda yetersiz görülürken; fen alanında eğitim gören öğrenciler için konferans salonları daha yüksek oranda yetersiz görülmüştür.

Öğrencilerin sınıf düzeyleri ile kampüsün kültürel alanlarından konferans salonlarının yeterli olup olmaması, açık mekânda yeme içme alanlarının yeterli olup olmaması ve otopark alanlarının yeterli olup olmaması arasında istatistiksel olarak anlamlı bir ilişki tespit edilmiştir $(p<0,05)$. Öğrencilerin sınıf düzeyi arttıkça konferans salonlarını yeterli bulmadıkları belirlenmiştir. Kampüsün kültürel alanlarından açık mekânda yeme-içme alanlarını sırasıyla 2. ve 3. sınıfta okuyan öğrencilerin, otoparkları ise 2. sınıfta 
okuyan öğrencilerin diğer sınıf düzeylerinde okuyan öğrencilere oranla daha yetersiz gördükleri belirlenmiştir.

Ayrıca ankette açık uçlu olarak sorulan "kampüste yapılar dışında kalan açık mekânlarda, yer almasını istedikleri alanlarla" ilgili soruya öğrencilerin çoğu; alış veriş merkezi (AVM), yaşam merkezleri, market, sokak hayvanları için kulübeler ve bisiklet yolları istediklerini belirtmişlerdir.

\section{IV.SONUC}

Bu çalışma ile Düzce Üniversitesi merkez kampüsünde eğitim gören öğrencilerin kampüsün rekreasyon amaçlı mekanlarının kullanımı ile ilgili kişisel görüşlerinin alınması ve bu alanların yeterliliklerinin değerlendirilmesi amaçlanmıştır. Yapılan analizler sonucunda çalışmaya ağırlıklı olarak katılanların kız öğrenci, 21-23 yaş aralığında, fen alanında eğitim aldığı, 2. sınıfta okuduğu ve öğrenci evlerinde konakladıkları belirlenmiştir.

Öğrencilerin kampüste günlük ortalama 5-6 saat geçirdikleri ve kampüsteki yeşil alanları; günlük 1-3 saat arası, hafta içi 4 saat ve üzeri, çoğunlukla ders sonrası ve hafta sonu ise 1-2 saat kullandıkları belirlenmiştir. Kız öğrencilerin yeşil alanları hem daha çok hem de sohbet etmek amaçlı kullandıkları belirlenmiştir. Fen ve sosyal alanında eğitim gören öğrencilerin yeşil alanları sohbet etme amaçlı, 3. ve 4. sınıf öğrencilerinin ise ders çalışma amaçlı kullandıkları görülmüştür. Öğrenciler kampüsteki yeşil alanları yeterli ve cazip bulmadıkları için kullanmadıklarını belirtmişlerdir.

Öğrencilerin yarısından fazlasının kampüsteki spor alanlarını kullandıkları, daha çok hafta sonları ve derslerinin olmadığı zamanlar kullanmayı tercih ettikleri görülmüştür. Erkek öğrencilerin spor alanlarını daha fazla kullandıkları ve futbol alanlarını tercih ettikleri, sağlık ve sosyal alanında eğitim gören ögrencilerin daha fazla spor alanlarını kullandıkları ve sağlık alanında eğitim gören öğrencilerin ise yüzme alanlarını tercih ettikleri belirlenmiştir.

Öğrencilerin büyük bir kısmının yürüyüş yollarını, yüzme havuzlarını, tenis kortlarını, kapalı spor salonlarını ve fitnes salonunu yetersiz bulduğu bunun yanı sıra basketbol sahalarını, voleybol sahalarını ve futbol sahalarını (stadyum) yeterli bulduğu ortaya konmuştur. Kız öğrenciler yürüyüş yollarını, erkek öğrenciler ise futbol sahalarını yetersiz bulmuşlardır.

Öğrencilerin yürüyüş yollarını; taşıt ve yaya trafiğinin ayrılmamış olması, yolların görsel açıdan tatmin edici olmaması ve yolların çok eğimli olması nedeniyle yetersiz gördükleri belirlenmiştir. Kız öğrencilerin yol kenarlarında bank vb. oturma elemanlarını yetersiz buldukları ve yollardaki döşemeleri yürüyüş için uygun bulmadıkları belirlenmiştir.

Öğrencilerin kampüsteki şenlik/konser alanlarını, konferans alanlarını ve tiyatro, sergi vb. alanları, kaferestoranları, açık mekânlarda yeme içme olanaklarını, otoparkları yetersiz buldukları belirlenmiştir. Sosyal alanında eğitim gören öğrenciler kampüsteki tiyatro, sergi vb. alanları, fen alanında eğitim gören öğrenciler ise konferans salonlarını yetersiz görmüşlerdir. Öğrencilerin sınıf düzeyi arttıkça konferans salonlarını yetersiz bulmaktadırlar.

Çalışmanın sonuçlarından yola çıkarak öğrencilerin genel olarak kampüsün rekreasyon amaçlı mekanlarını yeterli bulmadıkları söylenebilir. Öncelikli olarak kampüsün yeşil alanlarını gerek değişik renk-doku- formlarda bitkilendirme ile gerekse su öğeleri ve heykel vb. sanatsal öğeler ile daha cazip hale getirilmelidir. Yeşil alanlarda mevsimlik kullanımlara uygun oturma gruplarına ve yeterli donatı elemanlarına yer verilmelidir. Başıboş gezen sokak hayvanları için kulübeler yapılarak belli yerlere toplanmalıdırlar. Spor salonlarından öncelikle yoğun kullanılan fitnes salonunun yetersiz kaldığ1 düşünülerek sayısı arttırılmalıdır. Açık alanda voleybol sahalarına yer verilmelidir. Kampüs genelinde yolların eğimli olması nedeniyle yürüyüş yolları kenarlarında oturma-dinlenme alanlarına yer verilmelidir. Otopark yetersizliğinden dolayı yol kenarlarına park etmiş araçlar özellikle toplu taşımalar 
açısından oldukça sıkıntı yaratmaktadır. Otopark sorununun çözülmesi gerekmektedir. Kültürel alanlardan sinema, tiyatro ve sergi salonlarına ihtiyaç vardır. Kampüs genelinde kafe, restoran ve açık alanda yeme imkanı veren tesislerin sayısı arttırılmalıdır. Ayrıca öğrencilerin kampüs alanında ihtiyaç olduğunu belirttiği AVM, sinema salonları, yaşam merkezleri, bay-bayan kuaför, market ve bisiklet yolları vb. kullanımlara yer verilmelidir.

Sonuç olarak; Düzce üniversitesi eğitim- öğretim hayatına başladığı tarihten itibaren gün geçtikçe büyümekte ve gelişmektedir. Bu büyüme ve gelişim sırasında üniversitelerin öncelikli hedefi olan eğitim-öğretim ve araştırmaların yanı sıra sosyal, kültürel, sanatsal ve sportif etkinlikler için uygun rekreasyon amaçlı mekanlar yaratılarak öğrencilerin çevre ile ilişki kurabilmelerine, kendilerini geliştirme, yetiştirme ve sosyalleşmelerine zemin hazırlanmalıdır.

\section{KAYNAKLAR}

[1] İ. C. Kaba, "Türkiye'deki üniversitelerde kampüs rekreasyonu'nun mevcut durumu ve kampüs rekreasyon modellemesi," Yüksek Lisans tezi, Spor Yönetim Bilimleri Anabilim Dalı, Marmara Üniversitesi, İstanbul, Türkiye, 2009.

[2] A. N. Irgatoğlu, "Üniversite kampüsleri fiziksel gelişim ve tasarımı: Yozgat Bozok Üniversitesi Erdoğan Akdağ Kampüsü örneği," Yüksek Lisans tezi, Peyzaj Mimarlığı Bölümü, Ankara Üniversitesi, Ankara, Türkiye, 2011.

[3] L. Şahin, "Kampüslerin dış mekân tasarım ilkeleri açısından irdelenmesi; Işık Ayazağa Kampüsü örneği,” Yüksek Lisans tezi, Peyzaj Mimarlığı Bölümü, Tekirdağ Namık Kemal Üniversitesi, Tekirdağ, Türkiye, 2019.

[4] G. Ayvacı, "Üniversite kampüslerindeki dış mekân tasarımında kullanıcı gereksinimlerinin belirlenmesine yönelik bir araştırma," Doktora tezi, Peyzaj Mimarlığı Bölümü, İstanbul Teknik Üniversitesi, İstanbul, Türkiye, 2009.

[5] P. V. Turner, "Campus an American planning tradition," Landscape Journal, vol. 5, no. 1, pp. 66-67, 1986.

[6] K. Sönmezler, "Üniversiteler," Yüksek Lisans tezi, Mimarlık Bölümü, Mimar Sinan Üniversitesi, İstanbul, Türkiye, 1995.

[7] U. Erkman, Büyüme ve Gelişme Sorunları Açısından Üniversite Kampüslerinde Planlama ve Tasarım Sorunlar, İstanbul, Türkiye: İTÜ Mimarlık Fakültesi Baskı Atölyesi, 1990.

[8] R. P. Dober, Campus Desing, John Wiley \& Sons Inc., U.S.A. 1992.

[9] B. S. Sıramkaya ve K. Çınar, "Üniversite Kampüs yerleșkelerinde ortak kullanım mekânlarının incelenmesi: Selçuk Üniversitesi Aleaddin Keykubat kampüsü örneği," Selçuk Üniversitesi Mühendislik, Bilim ve Teknoloji Dergisi, c. 27. s. 2, ss. 61-72, 2012.

[10] C. Çağlar, "Kampus tipi üniversite modeline yaklaşım ve bunun Eskişehir Kentinde uygulanmasi," Yüksek Lisans tezi, Güzel Sanatlar Fakültesi, Ege Üniversitesi, İzmir, Türkiye, 1976.

[11] M. N. Türeyen, Yüksekögretim Kurumları Kampüsler, İstanbul, Türkiye: Tasarım Yayın Grubu, 2002.

[12] B. Erçevik ve F. Önal, "Üniversite kampüs sistemlerinde sosyal mekân kullanımları,” Megaron Journal, c. 6, s. 3, ss. 151-161, 2011. 
[13] İ. Tekeli, "Büyük kent dışı üniversitelerin kuruluş yeri sorunları üzerine," Mimarlık Dergisi, c. 10, s. 12 , ss. $36-40,1972$.

[14] T. Yamane, Temel Örnekleme Yöntemleri. (Çev: A. Esin, M. A. Bakır, C. Aydın ve E. Gürbüzsel), 1. bask1, İstanbul: Literatür Yayıncılık, ss. 53, 2001.

[15] M. B. Tolon, "Üniversite kampüslerı dış mekân tasarım ilkeleri ve Ankara Üniversitesi Gölbaşı Kampüsü peyzaj tasarımı,” Yüksek Lisans tezi, Peyzaj Mimarlığı Bölümü, Ankara Üniversitesi, Ankara, Türkiye, 2006.

[16] B. Erçevik, "Üniversitelerde sosyal mekân kullanımlarının incelenmesi: kent üniversitesi, kent içi ve kent dışı kampüsler," Yüksek Lisans tezi, Mimarlık Bölümü, Yıldız Teknik Üniversitesi, İstanbul, Türkiye, 2008.

[17] N. Çınar, "Üniversite kampüslerindeki peyzaj erişilebilirliğinin engelliler açısından irdelenmesi," Yüksek Lisans tezi, Peyzaj Mimarlığı Bölümü, Ankara Üniversitesi, Ankara, Türkiye, 2010.

[18] T. Düzenli, "Kampüs açık mekân olanaklarının gençlerin psikososyal yapısına bağlı olarak incelenmesi: K.T.Ü. Kanuni kampüsü örneği,” Doktora tezi, Peyzaj Mimarlığı Bölümü, Karadeniz Teknik Üniversitesi, Trabzon, Türkiye, 2010.

[19] T. Düzenli, S. Mumcu ve D. Akyol, "Üniversite kampüsü açık mekânlarının gençler tarafindan kullanım amaçlarının belirlenmesi," Uluslararası Sosyal Araştırmalar Dergisi, c. 10, s. 49, ss. 766-772, 2017.

[20] SPSS Base 12.0, Bilgisayar Programı, SPSS Institute Inc., 2003.

[21] K. Özdamar, Paket Programlar ile İstatistiksel Veri Analizi, 4. bask1, Eskişehir, Türkiye: Kaan Kitabevi, 2002.

[22] Ş. Kalaycı, SPSS Uygulamalı Çok Değişkenli İstatistik Teknikleri, 7. baskı, Ankara, Türkiye: Asil Basın Yayın Dağıtım, 2016.

[23] A. L. McFarland, T. Waliczek and J. Zajicek. "The relationship between student use of campus green spaces and perceptions of quality of life," HortTechnology, vol. 18, no. 2, pp. 232-238, 2008.

[24] T. M. Abu-Ghazzeh, "Communicating behavioral research to campus design - factors affecting the perception and use of outdoor spaces at the University of Jordan," Environment and Behavior, vol. 31, no. 6, pp. 764-804, 1999.

[25] J. Speake, S. Edmondson and H. Nawaz, "Everyday encounters with nature: Students' perceptions and use of university campus green spaces," Human Geographies: Journal of Studies and Research in Human Geography, vol. 7, no. 1, pp. 21-31, 2013.

[26] H. Müderrisoğlu ve S. Uzun, “Abant İzzet Baysal Üniversitesi Orman Fakültesi öğrencilerinin rekreasyonel eğilimleri,” Turkish Journal of Forestry, c. 5, s. 2, ss. 108-121, 2009.

[27] J. J. Coakley and A. White, "Making decisions: Gender and sports participations among British adolescents," Sociology of Sport Journal, vol. 9, pp. 20-35, 1992.

[28] S. L. Greendorfer, "Gender role stereotypes and early childhood socializations," Psychology of Women Quarterly, vol. 11, pp. 327-340, 1993. 